\title{
Calculation of the carbon footprint of Ontario wheat
}

\author{
Jacqueline Ann Ho
}

\begin{abstract}
This study was conducted under the supervision of Professor Claudia Wagner-Riddle, School of Environmental Sciences, University of Guelph
\end{abstract}

\begin{abstract}
Increasing consumer awareness of the environmental impact of food production has prompted interest in locally grown food in Ontario. The research reported here had the objective of quantifying the carbon footprint of Ontario grown wheat. A spreadsheet was developed and populated with data and emission coefficients gathered through consultation of the literature. The spreadsheet expresses the carbon footprint in the life cycle of Ontario wheat in $\mathrm{CO}_{2}$ equivalent $\left(\mathrm{kg} \mathrm{CO}_{2}\right)$. The life cycle of wheat includes production, transportation, the use of machinery and application of agricultural chemicals such as pesticides and fertilizers. Since there are insufficient industrial data of manufacture of machines, they were not included in the calculations. The accuracy of this spreadsheet was examined by comparing its results with results of the Agriculture and Agri-Food Canada (AAFC) Greenhouse Gas (GHG) Calculator. The total farm emission of the AAFC GHG Calculator was 3960.2 $\mathrm{Mg} \mathrm{CO}_{2}$, while the created spreadsheet had a result of 2963.1 $\mathrm{Mg} \mathrm{CO}_{2}$. The spreadsheet has a lower emission than AAFC GHG Calculator because machine manufacture was not included in the spreadsheet. For individual categories agreement was quite close, most categories are within $90 \%$ agreement. As a conclusion, results between AAFC GHG Calculator and spreadsheets are similar hence demonstrate the accuracy of the spreadsheet created. Fertilizer production and direct emission from the soil were responsible for $89 \%$ of the GHG emissions from Ontario grown wheat.
\end{abstract}

$\mathrm{L}$ ife-cycle analysis (LCA) is a computtional tool used to assess the greenhouse gas budget of an end-product throughout its whole life cycle. The life cycle of wheat includes production, transportation, use of machinery and application of agricultural chemicals such as pesticides and fertilizers.

Greenhouse gas (GHG) is released during the manufacture of pesticides, which fomumation, packaging and transportaion of herbicides, insecticides and fungicides from manufacture to farm according to West and Marland [1] and Nagy [2].

Machinery use and manufacture release GHGs through burning of fossil fuel during field operations and manufacture of farm equipment (e.g. tractors). All on-farm operations including application of pesticides and fertilizers are integrated into this LCA.

Production of fertilizer includes the extraction of nutrients, manufacture of fertilizer and transportation of minerals to the production facility, supply centre, and the site of application. Energy used in transportation is 0.7 and 1.4 $\mathrm{MJ} / \mathrm{Mg}-\mathrm{km}$ by railroad and truck respectively according to West and Marland [1]. When fertilizers are added to agricultural soil, they undergo transformation through nitrification and denitrification, which releases $\mathrm{N}_{2} \mathrm{O}$ into the atmosphere. Also, the crop residue contains nitrogen, which decomposes to release nitrogen. All formulas and emission factors were obtained from Rochette et al [3].
After fertilizers are applied, some portion leaches while some is volatilized, and these nitrogen losses can result in indirect $\mathrm{N}_{2} \mathrm{O}$ emission. Transportation releases greenhouse gas by burning fuels such as gasoline and diesel. On-road transportation such as trucks and non-road transportation such as railway are necessary in agriculture for tranferring the crop product from the farmland to the market. Care was taken to aviod double counting of the transportation of pesticides and fertilizers from factory to farmland.

This paper will detail the methodologies and emission factors used in the spreadsheet to quantify the carbon footprint of wheat. The results are compared with Agriculture and Agri-Food Canada (AAFC) calculator for accuracy assurance.

\section{Methodology}

\section{Pesticides}

Pesticides are input as the active ingredient application rate $(\mathrm{kg}$ a.i./ha). The formula used is:

$$
\begin{aligned}
\mathrm{CO}_{2} \text { eq emission } & \left(\frac{\mathrm{kgCO}}{h a}\right) \\
& =\text { Emission Factor }\left(\frac{\mathrm{kgCO}}{\mathrm{kga.i.}}\right) \\
& \times \text { Application rate }\left(\frac{\mathrm{kga.i.}}{\mathrm{ha}}\right)
\end{aligned}
$$

Emission factors for insecticides and fungicides used are $4931.9 \mathrm{~kg} \mathrm{C} / \mathrm{Mg}$ and $5177.5 \mathrm{~kg} \mathrm{C} / \mathrm{Mg}$ respectively [1]. 
Emission factors for herbicide were derived from Nagy[2], who divided the emission factor by the average carbon content ( $\mathrm{kg} \mathrm{C} / \mathrm{MJ}$ a.i.) to obtain the kilograms of carbon per kilogram of active ingredients ( $\mathrm{kg} \mathrm{C} / \mathrm{kg}$ a.i.) (Table 1).

All emission factors were converted to kilograms of carbon dioxide equivalent per kilogram of active ingredient $\left(\mathrm{kg} \mathrm{CO}_{2} / \mathrm{kg}\right.$ a.i.). For example, the emission factor for insecticide is $4391.9 \mathrm{~kg} \mathrm{C} / \mathrm{Mg}$, to convert it to $\mathrm{CO}_{2}$ equivalent per kilograms of active ingredient $\left(\mathrm{kg} \mathrm{CO}_{2} / \mathrm{kg}\right.$ a.i.):

$$
\begin{aligned}
4931.9\left(\frac{\mathrm{kg} \epsilon}{\mathrm{Mga.i.}}\right) & \times \frac{1}{1000}\left(\frac{\mathrm{Mga.i.}}{\mathrm{kga.i.}}\right) \times \frac{1(\mathrm{~mol})}{12(g \in)} \\
& \times \frac{44(\mathrm{gCO})}{1(\mathrm{~mol})}=18.1\left(\frac{\mathrm{kgCO}}{\mathrm{kga.i.}}\right)
\end{aligned}
$$

As another example, the herbicides Achieve 80 DG has an emission of $2.9 \mathrm{~kg} \mathrm{C} / \mathrm{kg}$ a.i. (Table 1), so to convert it to $\mathrm{CO}_{2}$ eqivalent:

$$
2.9\left(\frac{\mathrm{kg} C}{\mathrm{kga.i.}}\right) \times \frac{44\left(\mathrm{gCO}_{2}\right)}{1(\mathrm{~mol})} \times \frac{1(\mathrm{~mol})}{12(\mathrm{~g} \mathrm{C})}=10.6\left(\frac{\mathrm{kgCO}}{\mathrm{kga.i.}}\right)
$$

\section{Machinery Use}

Machinery use and manufacture releases GHGs through burning of fossil fuel during field operations and manufacture of farm equipment (e.g. tractors). All on-farm

Table 1 Herbicide Emission Factor obtained from Nagy [2]

\begin{tabular}{|l|r|r|r|r|}
\hline & \multicolumn{2}{|c|}{ year 2000} & \multicolumn{2}{c|}{ year 1996 } \\
\hline Herbicides & MJ/kg a.i. & kg C/kg a.i. & MJ/kg a.i. & kg C/kg a.i. \\
\hline Achiever 80 DG & 229 & 2.9 & 313.8 & 3.9 \\
\hline Amber & 267.3 & 3.3 & 366.2 & 4.6 \\
\hline Aatrex Nine-O & 158.2 & 2 & 216.7 & 2.7 \\
\hline Bladex 90 DF & 168.6 & 2.1 & 231 & 2.9 \\
\hline Lexone DF & 437.3 & 5.5 & 599.1 & 7.5 \\
\hline Odyssey (1997) & 152.1 & 1.9 & 208.4 & 2.6 \\
\hline Secor 75 DF & 146 & 1.8 & 200 & 2.5 \\
\hline Venture & 437.3 & 5.5 & 599.1 & 7.5 \\
\hline Bladex L & 168.6 & 2.1 & 231 & 2.9 \\
\hline Glean & 309.3 & 3.9 & 423.7 & 5.3 \\
\hline Lorox DF & 237.9 & 3 & 325.9 & 4.1 \\
\hline Muster & 246.3 & 3.1 & 337.4 & 4.2 \\
\hline Refine Extra & 246.3 & 3.1 & 337.4 & 4.2 \\
\hline Stampede EDF & 184.4 & 2.3 & 252.6 & 3.2 \\
\hline Assert & 234.2 & 2.9 & 320.8 & 4 \\
\hline Avenge & 369.7 & 4.6 & 506.5 & 6.3 \\
\hline Banvel & 245.3 & 3.1 & 336 & 4.2 \\
\hline Basagran & 359.9 & 4.5 & 493 & 6.2 \\
\hline Dyvel DS & 104.5 & 1.3 & 143.2 & 1.8 \\
\hline
\end{tabular}

operations including application of pesticides and fertilizers are discussed in this section. All fuel consumptions (L/ha) for different operations were collected from Bowers [4] and Dyer and Desjardins [5]. The number of times of operation performed annually is specified by spreadsheet users. The formula is:

$$
\begin{aligned}
& \mathrm{CO}_{2} \text { eq }\left(\frac{\mathrm{kgCO}_{2}}{\mathrm{ha}}\right) \\
& =\text { Emission factor }\left(\frac{\mathrm{kgCO}}{L}\right) \\
& \times \text { Fuel Consumption for each operation }\left(\frac{L}{h a}\right) \\
& \times \text { Times of operation performed } \\
& \times \text { Fuel production ratio }
\end{aligned}
$$

The fuel production ratio is the ratio of energy content in fuel to energy used to mine, refine and transport fuel to farmers. The energy content and production values were obtained from Cervinka [6]. An example of the derivation of ratio for gasoline is shown below:

$$
\begin{gathered}
\text { Ratio }=\text { Total energy cost } \div \text { Energy content } \\
=42.3 \div 32.2=1.24
\end{gathered}
$$

Canada's Greenhouse Gas Inventory 1990-2001 lists all the emission factors for on-road transportation, non-road vehicles and diesel rail transportations [7]. For example, the emission factor for Heavy-Duty Diesel Vehicles (HDDV) is $2730 \mathrm{~g} \mathrm{CO}_{2} / \mathrm{L}$ and was converted to $2.73 \mathrm{~kg} \mathrm{CO} / \mathrm{L}$. The range of carbon equivalent emission for moldboard plowing is 13.4 to $20.1 \mathrm{~kg} \mathrm{CE} / \mathrm{ha}$, which is also equivalent to 49.1 $73.7 \mathrm{~kg} \mathrm{CO} / \mathrm{ha}$ [7]. In the spreadsheet, for moldboard plowing:

$$
\begin{gathered}
\text { Fuel consumption }=17.49\left(\frac{\mathrm{L}}{\mathrm{ha}}\right) \\
\text { Emission factor }=2.73\left(\frac{\mathrm{kgCO}}{\mathrm{L}}\right) \\
\text { Fuel production ratio }=1.24
\end{gathered}
$$

Using the values above, the $\mathrm{CO}_{2}$ eq emission woud be:

$$
\begin{aligned}
\mathrm{CO}_{2} \text { eq emission } & =2.73\left(\frac{\mathrm{kgCO} 2}{L}\right) \times 17.49\left(\frac{\mathrm{L}}{\mathrm{ha}}\right) \times 1.24 \\
& =59.2\left(\frac{\mathrm{kgCO} 2}{\mathrm{ha}}\right)
\end{aligned}
$$

This emission for moldboard plowing was compared with Lal[8], who stated emissions are within the range of 49.1$73.7 \mathrm{~kg} \mathrm{CO} / \mathrm{ha} \mathrm{[7].}$

\section{Machine Manufacture}

The weight of machinery in kilograms is user-specific in our spreadsheet. The formula for emission is shown below:

$$
\begin{aligned}
\mathrm{CO}_{2} \text { eq emission } & (\mathrm{kgCO}) \\
& =\text { Energy content } \\
& \times \text { Emission factor }\left(\frac{\mathrm{kgCO}}{G J}\right) \\
& \times \text { Weightof machine }(\mathrm{kg})
\end{aligned}
$$

All the energy contents of equipement were obtained from Bower [4]. 
Fertilizer Production and Direct and Indirect Emission from Fertilizer

The emissions related to fertilizers are divdided into three sections.

Part A: Methodology for Nitrogen, Potassium and Potash Fertilizer Production

Part B: Methodology for Direct Emission from Nitrogen Fertilizers

Part C: Methodology for Indirect Emissions from Nitrogen Fertilizers

\section{Part A: Nitrogen, Potassium and Potash Fertilizer Production}

Production of fertilizer includes the extraction of nutrients, manufacture fertilizer and transportation of the mineral to the production facility, supply centre, and the site of application. Energy used in transportation is 0.7 and 1.4 $\mathrm{MJ} / \mathrm{Mg} / \mathrm{km}$ by railroad and truck respectively [1].

The nutrient application rate in kilogram of nutrient per hectare is user-specified in the spreadsheet. The formula for emission calculation is shown below:

$\mathrm{CO}_{2}$ eq emission $\left(\mathrm{kg} \mathrm{CO} \mathrm{O}_{2}\right)$

$$
\begin{aligned}
& =\text { Application rate }\left(\frac{\mathrm{kg} \text { nutrient }}{\mathrm{ha}}\right) \\
& \times \text { Emission factor }\left(\frac{\mathrm{kgCO}}{\mathrm{kg} \text { nutrient }}\right)
\end{aligned}
$$

Emission factors were collected from West and Marland [1] and Nagy [2]. For nitrogen based fertilizers, emission factors range from $2.6 \mathrm{~kg} \mathrm{CO}_{2} / \mathrm{kg} \mathrm{N}$ to $4.3 \mathrm{~kg} \mathrm{CO} / \mathrm{kg} \mathrm{N}$. Potash $\left(62 \% \mathrm{~K}_{2} \mathrm{O}\right)$ has an emission factor of $0.24 \mathrm{~kg} \mathrm{CO}_{2} / \mathrm{kg} \mathrm{K}_{2} \mathrm{O}$ while Phosphorus $\left(55 \% \mathrm{P}_{2} \mathrm{O}_{5}\right)$ has an emission factor of 0.57 $\mathrm{kg} \mathrm{CO}_{2} / \mathrm{kg} \mathrm{P}_{2} \mathrm{O}_{5}$.

Emission factors for nitrogen fertilizer range from 0.9 to $1.8 \mathrm{~kg} \mathrm{C} / \mathrm{kg}$, which is equivalent to $3.3-3.6 \mathrm{~kg} \mathrm{CO} / \mathrm{kg}$ [7]. The fertilizer range of the spreadsheet is less than Lal [7], who however, has less updated sources than Nagy [2]. Therefore, advanced technology has created more efficient fertilizer which release fwer emissions.

\section{Part B: Direct Emission from Nitrogen Fertilizers}

When fertilizers are added to agriculture soil, they undergo transformation through nitrification and denitrification, which releases $\mathrm{N}_{2} \mathrm{O}$ into the atmosphere. Also, the crop residue contains nitrogen, which decomposes to release nitrogen. All formulas and emission factors were obtained from estimation of soil $\mathrm{N}_{2} \mathrm{O}$ emission by Rochette et al [3]

Direct emissions are influenced by many factors such as amount of fertilizer applied $\left(\mathrm{N}_{2} \mathrm{O}\right.$ fertilizer), amount of crop residue returned to soil $\left(\mathrm{N}_{2} \mathrm{O}\right.$ residue), soil tillage $\left(\mathrm{N}_{2} \mathrm{O}\right.$ till) and soil texture $\left(\mathrm{N}_{2} \mathrm{O}\right.$ text) [3]. Therefore, each category has its own formula for emission calculation.

The inputs specified by the spreadsheet user include nitrogen application rate $(\mathrm{kg} / \mathrm{ha})$, mass of nitrogen in crop residue returned to soil $(\mathrm{kg} / \mathrm{ha})$, fraction of farm area with fine ( $\mathrm{F}$ fine), medium ( $\mathrm{F}$ med) and coarse ( $\mathrm{F} \mathrm{co}$ ) textured soil and Fraction of farm area under tillage (F till). To classify each texture, fine texture stands for clay, medium texture corresponds to loamy clay, loamy sand and loam, while coarse texture represents sand.

The formulas for each category are shown below:

1. $\mathrm{N}_{2} \mathrm{O}_{\text {input }}\left(\frac{\mathrm{kg} \mathrm{N} \mathrm{N}_{2} \mathrm{O} N}{\mathrm{ha}}\right)=\mathrm{N}_{2} \mathrm{O}_{\text {residue }}+\mathrm{N}_{2} \mathrm{O}_{\text {fertilizer }}$

a. $\quad \mathrm{N}_{2} \mathrm{O}_{\text {residue }}\left(\frac{\mathrm{kg} \mathrm{N} \mathrm{N}_{2} \mathrm{O}-\mathrm{N}}{\mathrm{ha}}\right)=E F\left(\frac{\mathrm{kg} \mathrm{N} \mathrm{N}_{2} \mathrm{O}-\mathrm{N}}{\mathrm{kg} \mathrm{N}}\right) \times$ Weight of crop residue $\left(\frac{\mathrm{kg} \mathrm{N}}{\mathrm{ha}}\right)$

b. $\quad \mathrm{N}_{2} \mathrm{O}_{\text {fertilizer }}\left(\frac{\mathrm{kg} \mathrm{N} \mathrm{N}_{2} \mathrm{O}-\mathrm{N}}{\mathrm{ha}}\right)=E F\left(\frac{\mathrm{kg} \mathrm{N} \mathrm{N}_{2} \mathrm{O}-\mathrm{N}}{\mathrm{kgN}}\right) \times$ Nitrogen application rate $\left(\frac{\mathrm{kgN}}{\mathrm{ha}}\right)$

2. $N_{2} O_{\text {text }}\left(\frac{k g N_{2} O-N}{h a}\right)=N_{2} O_{\text {input }} \times\left\{\left[\left(R F_{\text {fine }}-1\right) \times\right.\right.$ $\left.F_{\text {fine }}\right]+\left\{\left[\left(R F_{\text {medium }}-1\right) \times F_{\text {medium }}\right]+\left\{\left[\left(R F_{\text {coarse }}-\right.\right.\right.\right.$ 1) $\left.\left.\times F_{\text {coarse }}\right]\right\}$

3. $\mathrm{N}_{2} \mathrm{O}_{\text {till }}\left(\frac{\mathrm{kg} \mathrm{N} \mathrm{N}_{2} \mathrm{O}-\mathrm{N}}{\mathrm{ha}}\right)=\mathrm{N}_{2} \mathrm{O}_{\text {input }} \times\left\{\left[\left(R F_{\text {till }}-1\right) \times F_{\text {till }}\right]\right.$

Emission factors vary with regions (Table 2). Also, all formulas were expressed in $\mathrm{kg} \mathrm{N}_{2} \mathrm{O}$, to express the results in $\mathrm{CO}_{2}$ equivalent. The formula was multiplied by ratio of molar mass of $\mathrm{N}_{2} \mathrm{O}$ and $\mathrm{N}_{2} \mathrm{O}-\mathrm{N}$, which are $44 \mathrm{~kg} \mathrm{~N} \mathrm{~N}_{2} \mathrm{O}$ and 28 $\mathrm{kg} \mathrm{N}_{2} \mathrm{O}-\mathrm{N}$ respectively. In addition, the global warming potential unit of $\mathrm{N}_{2} \mathrm{O}$ is $310 \mathrm{CO}_{2}$ thus the formula was multiplied by 310 to express the emission in terms of $\mathrm{CO}_{2}$ [8].

An example of calculation is given using $\mathrm{RF}_{\text {till }}=1.1$ and with soil texture in Ontario-Quebec region $(\mathrm{EF}=0.012)$ :

$$
N_{2} O_{\text {residue }}\left(\frac{k g N_{2} O-N}{h a}\right)=0.012\left(\frac{k g N_{2} O-N}{k g N}\right) \times 0\left(\frac{k g N}{h a}\right)
$$

\begin{tabular}{|c|c|c|c|c|}
\hline Region & & $\begin{array}{l}\text { Ontario- } \\
\text { Quebec }\end{array}$ & $\begin{array}{l}\text { Prairies } \\
\text { (Brown and } \\
\text { Dark Brown) } \\
\end{array}$ & $\begin{array}{l}\text { Prairies } \\
\text { (Black and } \\
\text { Gray) }\end{array}$ \\
\hline \multicolumn{2}{|c|}{$\mathrm{EF}\left(\mathrm{kg} \mathrm{N}_{2} \mathrm{O}-\mathrm{N} / \mathrm{kg} \mathrm{N}\right)$} & 0.012 & 0.0016 & 0.0008 \\
\hline \multirow[b]{2}{*}{$\mathrm{RF}_{\text {till }}$} & $\begin{array}{l}\text { conventional } \\
\text { tillage }\end{array}$ & 1 & 1 & \\
\hline & $\begin{array}{l}\text { minimum tillage } \\
\text { and no-till }\end{array}$ & 1.1 & 0.8 & 0.8 \\
\hline \multirow[b]{2}{*}{$\mathrm{RF}_{\text {text }}$} & $\begin{array}{l}\text { conventional } \\
\text { tillage }\end{array}$ & 1.2 & & \\
\hline & $\begin{array}{l}\text { minimum tillage } \\
\text { and no-till }\end{array}$ & 0.8 & 1 & 1 \\
\hline \multicolumn{2}{|c|}{$\mathrm{R}_{\text {leaching crop }}$} & 0.25 & 0.05 & 0.1 \\
\hline \multicolumn{2}{|c|}{$E F_{\text {leaching }}$} & 0.0125 & 0.0125 & 0.0125 \\
\hline \multicolumn{2}{|c|}{$\mathrm{R}_{\text {volatilization crop }}$} & 0.1 & 0.1 & 0.1 \\
\hline \multicolumn{2}{|c|}{ EF volatilization crop } & 0.01 & 0.01 & 0.01 \\
\hline
\end{tabular}

Table 2 Emission Factors for different regions [3]. 


$$
\begin{aligned}
\mathrm{N}_{2} \mathrm{O}_{\text {fertilizer }}\left(\frac{\mathrm{kg} \mathrm{N} \mathrm{N}_{2} \mathrm{O}-\mathrm{N}}{\mathrm{ha}}\right) & \\
& =0.012\left(\frac{\mathrm{kg} \mathrm{N} \mathrm{N}_{2} \mathrm{O}-\mathrm{N}}{\mathrm{kgN}}\right) \times 90\left(\frac{\mathrm{kg} \mathrm{N}}{\mathrm{ha}}\right) \\
& =1.08
\end{aligned}
$$

Hence,

$$
\begin{aligned}
& \mathrm{N}_{2} \mathrm{O}_{\text {input }}\left(\frac{k g \mathrm{~N}_{2} \mathrm{O}-\mathrm{N}}{\mathrm{ha}}\right)=0+1.08=1.08 \\
& \mathrm{~N}_{2} \mathrm{O}_{\text {text }}\left(\frac{\mathrm{kgN} \mathrm{N}_{2} \mathrm{O}-\mathrm{N}}{h a}\right) \\
& =1.08 \times(1.2-1) \times 1.08 \times(0.8-1) \\
& \times 0+1.08 \times(0.8-1)=0.216
\end{aligned}
$$

Therefore,

$$
\begin{aligned}
& \text { Direct } \mathrm{N}_{2} \mathrm{O} \text { emission in } \mathrm{CO}_{2} \text { eq } \\
& =\left(1.08+0.216+0.108\left(\frac{k g N_{2} O-N}{h a}\right)\right) \\
& \times \frac{44 \mathrm{kgN}_{2} \mathrm{O}}{28 \mathrm{kgN}_{2} \mathrm{O}-\mathrm{N}} \times \frac{310 \mathrm{kgCO}_{2}}{1 \mathrm{kgN}_{2} \mathrm{O}} \\
& =683.9 \frac{\mathrm{kgCO}}{\mathrm{ha}}
\end{aligned}
$$

\section{Part C: Methodology for Indirect Emission from fertilizers}

After fertilizers are applied, some portion leaches while some is volatilized. These nitrogen losses are described as indirect $\mathrm{N}_{2} \mathrm{O}$ emissions. Indirect $\mathrm{N}_{2} \mathrm{O}$ emission followed the methodology described in Helgason et al [9].

Nitrogen fertilizer applied in kilograms per hectare is input by spreadsheet users. The emission formulas are listed below:

$$
\begin{aligned}
& \mathrm{N}_{2} \mathrm{O} \text { leached }\left(\frac{\mathrm{kg} \mathrm{N}_{2} \mathrm{O}-\mathrm{N}}{\mathrm{ha}}\right) \\
& =N \text { fertilizer applied }\left(\frac{\mathrm{kg}}{\mathrm{ha}}\right) \\
& \times R_{\text {leaching crop }} \times E F_{\text {leaching crop }} \\
& \mathrm{N}_{2} \mathrm{O} \text { volatilized }\left(\frac{\mathrm{kg} \mathrm{N} \mathrm{N}_{2} \mathrm{O}-\mathrm{N}}{\mathrm{ha}}\right) \\
& =N \text { fertilizer applied }\left(\frac{\mathrm{kg}}{\mathrm{ha}}\right) \\
& \times R_{\text {volatilization crop }} \times E F_{\text {volatilization crop }}
\end{aligned}
$$

Emission factors vary with region (Table 2). Similarly to direct emissions, $\mathrm{N}_{2} \mathrm{O}$ leached and volatilzed were both exporessed in $\mathrm{kg} \mathrm{N}_{2} \mathrm{O}-\mathrm{N}$. In order to express the results in $\mathrm{CO}_{2}$ equivalent, the formula was multiplied by ratio of the molar mass of $\mathrm{N}_{2} \mathrm{O}$ and $\mathrm{N}_{2} \mathrm{O}-\mathrm{N}$ and the global warming potential unit of $\mathrm{N}_{2} \mathrm{O}: 44 \mathrm{~kg} \mathrm{~N}_{2} \mathrm{O} / 28 \mathrm{~N}_{2} \mathrm{O}-\mathrm{Nx} 310 \mathrm{~N}_{2} \mathrm{O} / 1 \mathrm{CO}_{2}$

For example, if $90 \mathrm{~kg} / \mathrm{ha}$ of $\mathrm{N}$ fertilizer is applied:

$$
\begin{gathered}
\mathrm{N}_{2} \mathrm{O} \text { leached }\left(\frac{\mathrm{kg} \mathrm{N} \mathrm{O}-\mathrm{N}}{\mathrm{ha}}\right)=90 \frac{\mathrm{kg}}{\mathrm{ha}} \times 0.25 \times 0.125 \\
=0.28
\end{gathered}
$$

$$
\begin{aligned}
\mathrm{N}_{2} \mathrm{O} \text { volatilized } & \left(\frac{\mathrm{kg} \mathrm{N} \mathrm{N}_{2} \mathrm{O}-\mathrm{N}}{\mathrm{ha}}\right)=90 \frac{\mathrm{kg}}{\mathrm{ha}} \times 0.1 \times 0.01 \\
& =0.09
\end{aligned}
$$

Hence,

$$
\begin{aligned}
\text { Total indirect } & \mathrm{N}_{2} \mathrm{O} \text { emission in } \mathrm{CO}_{2} \text { eq } \\
& =\left(0.28+0.09\left(\frac{\mathrm{kg} \mathrm{N} \mathrm{N}_{2} \mathrm{O}-\mathrm{N}}{h a}\right)\right) \\
& \times \frac{44 \mathrm{kgN}_{2} \mathrm{O}}{28 \mathrm{kgN}_{2} \mathrm{O}-\mathrm{N}} \times \frac{310 \mathrm{kgCO}_{2}}{1 \mathrm{kgN}_{2} \mathrm{O}} \\
& =12.3\left(\frac{\mathrm{kg} \mathrm{CO}}{\mathrm{ha}}\right)
\end{aligned}
$$

\section{Transportation}

Tranportation releases greenhouse gas by burning fuels such a gasoline and diesel. On-road transportation such as railway are necessary in agriculture for transferring the crop product from the farmland to the market. Please note that transportation of pesticides and fertilizer from the manufacture to the farmland are included in Pesticide category and Fertilizer category discussed above.

Canada's Greenhouse Gas Inventory 1990-2001 [8] and Bushi list the emissions from transportation [10]. Canada's Greenhouse Gas Inventory 1990-2002 lists the emission factor for gasoline-based vehicles as $2.36 \mathrm{~kg}$ $\mathrm{CO}_{2} / \mathrm{L}$, and for diesel-based vehicles as $2.73 \mathrm{~kg} \mathrm{CO}_{2} / \mathrm{L}$.

Inputs by spreadsheet users include the distance travelled in kilometers and the number of cars. The formulas used are listed below:

$$
\begin{aligned}
& \text { Emission }\left(\frac{\mathrm{kgCO}}{\mathrm{Mg}_{2}}\right) \\
& =\text { Emission in } \mathrm{CO}_{2} \text { eq }\left(\mathrm{kgCO}_{2}\right) \\
& \div \text { Weight of wheat transported }(\mathrm{Mg} \text { wheat })
\end{aligned}
$$

Fuel efficiencies were derived from SGA [11], while bulk density and load capacities were obatined from Börjesson [12].

\section{RESULTS AND DISCUSSION}

The results of the spreadsheet were compared with the results from the AAFC GHG Calculator. The results are discussed in the order that displayed in the AAFC GHG Calculator.

\section{AAFC GHG Calculator Inputs}

For the location tab, the province Ontario (Ecodistrict 413) with soil type as Humo-Ferric Podizol and soil texture as Loamy Clay are selected as inputs. For land use tab, the total farm area and crop is set as 2000 hectares, while pasture, yard, roadways and other are set as zero. As for history of the land use, we set there are zero crop land converted to permanent cover. Also, the tillage intensity is set as intensive 20 years ago and presently. For the crop information, 2000 hectares of winter wheat is selected with $90 \mathrm{kgN} / \mathrm{ha}$ of nitrogen fertilizer rate applied in the spring. 
The yield is $3534 \mathrm{~kg} / \mathrm{ha}$ with zero percent straw removal. The rest of the tabs (Manure and Livestock) were not applicable to this study.

\author{
AAFC GHG Calculator Results \\ Cropping $\mathrm{N}_{2} \mathrm{O}\left(\mathrm{Mg} \mathrm{CO}_{2}\right.$ eq) \\ Direct $\mathrm{N}_{2} \mathrm{O}$ emissions $\left(\mathrm{Mg} \mathrm{CO} \mathrm{CO}_{2}\right.$ eq) \\ $+/-<60 \% \quad$ Units: $\mathbf{k g ~ N} \mathrm{N}_{2} \mathrm{O}-\mathrm{N}$ \\ Fertilizer: 3907.8 \\ Residue: 1062.3 \\ Fallow: 0.0 \\ Improved Pasture: 0.0 \\ Organic Soil: 0.0 \\ Total Direct $\mathrm{N}_{2} \mathrm{O}$ emissions $\left(\mathrm{Mg} \mathrm{CO}_{2}\right.$ eq): 2311.8 \\ Indirect $\mathrm{N}_{2} \mathrm{O}$ emissions $\left(\mathrm{Mg} \mathrm{CO}_{2}\right.$ eq) \\ $+/->60 \% \quad$ Units: $k g \mathrm{~N}_{2} \mathrm{O}-\mathrm{N}$ \\ Leaching: 562.5 \\ Volatilization: 180.0 \\ Total Indirect $\mathrm{N}_{2} \mathrm{O}$ emissions $\left(\mathrm{Mg} \mathrm{CO}_{2}\right.$ eq): 345.4 \\ Energy $\mathrm{CO} 2(\mathrm{Mg} \mathrm{CO} 2 \mathrm{eq})$ \\ +/- $<20 \% \quad$ Units: kg $\mathrm{CO}_{2}$ \\ Fuel, Herbicide and Machinery: 857220.0 \\ Production of Fertilizers: 460744.0 \\ Total Energy $\mathrm{CO}_{2}\left(\mathrm{Mg} \mathrm{CO}_{2}\right.$ eq): 1318.0 \\ Total farm emissions ( $\left.\mathrm{Mg} \mathrm{CO}_{2} \mathrm{eq}\right) \quad+/-<60 \%$ \\ Total farm emissions ( $\left.\mathrm{Mg} \mathrm{CO}_{2} \mathrm{eq}\right): 3960.2$
}

\section{Spreadsheet Inputs}

The input for the spreadsheet was the same as the input of the AAFC GHG Calculator. However, some input such as pesticide weights ( $\mathrm{kg}$ a.i.) is not required for the AAFC GHG Calculator. Hence, a resonable input for pesticide was enetered into the spreadsheet.

For direct $\mathrm{N}_{2} \mathrm{O}$ emission, when $90 \mathrm{kgN} / \mathrm{ha}$ fertilizer rate and 2000 ha of crop area are entered in the AAFC GHG Calculator, the direct $\mathrm{N}_{2} \mathrm{O}$ emission is $3907.8 \mathrm{~kg} \mathrm{~N}_{2} \mathrm{O}-\mathrm{N}$ as shown above. To convert the results in $\mathrm{CO}_{2}$ equivalent:

$$
\begin{aligned}
3907.8 \mathrm{~kg} \mathrm{~N} \mathrm{~N}_{2} \mathrm{O}-\mathrm{N} & \times \frac{44 \mathrm{~N}_{2} \mathrm{O}}{28 \mathrm{~N}_{2} \mathrm{O}-\mathrm{N}} \times \frac{310 \mathrm{CO}_{2}}{1 \mathrm{~N}_{2} \mathrm{O}} \\
& =1,903,657 \mathrm{~kg} \mathrm{CO} \mathrm{CO}_{2}
\end{aligned}
$$

Hence, the direct $\mathrm{N}_{2} \mathrm{O}$ emission in $\mathrm{CO}_{2}$ equivalent is $1,903.7$ $\mathrm{Mg} \mathrm{CO}$ in the AAFC GHG Calculator, which is similar to the results in the spreadsheet of $2,092 \mathrm{Mg} \mathrm{CO}_{2}$.

For indirect $\mathrm{N}_{2} \mathrm{O}$ emission, the output is $361.7 \mathrm{Mg} \mathrm{CO}_{2}$ with the same inputs. This is similar to the AAFC GHG Calculator (345.4 $\mathrm{Mg} \mathrm{CO}_{2}$ ).

For fuel, herbicide and machinery, since the total emission of fuel, herbicide and machinery are combined in the AAFC GHG Calculator, the calculation follows for comparison purposes. The Ontario input of fuel machinery were obtained from Dyer and Desjardin [5]. In addition, SGA provides the regional mean of GHG emissions in $\mathrm{kg}$ $\mathrm{CO}_{2}$ equivalent per hecatare for major farm machinery operations, without any adjustment for specific farm types. For comparison purposes, a few operations were used as input: moldboard plow, disc-tilled soil, field sprayer, spread fertilizer, rotary hoe, broadcast seeder, combine, harvester and grain wagon [11]. As a consequence, emission for machinery fuel is $572.2 \mathrm{Mg} \mathrm{CO}_{2}$. For pesticides, the input are obtained from Lal, who provides the carbon budget of weed control in carbon equivalent per hectare ( $\mathrm{kg} \mathrm{CE} / \mathrm{ha})$ for different intensity of tillage. Weed control for wheat with high tillage is $9.1 \mathrm{~kg}$ CE/ha, which is equal to $33.4 \mathrm{~kg}$ $\mathrm{CO}_{2} /$ ha. Consequently, the calculation gives an emission of total $199.5 \mathrm{Mg} \mathrm{CO}$. To sum up fuel, herbicide, and machinery, the calculation resulted in a total of $771.8 \mathrm{Mg}$ $\mathrm{CO}_{2}$, which is approximately $100 \mathrm{Mg} \mathrm{CO}$ less than AAFC GHG Calculator's result (852.2 $\mathrm{Mg} \mathrm{CO}$ ). The difference between the two results is possibly due to manufacture of machinery, as the calculation has excluded manufacture of machinery while the AAFC GHG Calclator has included that factor. As a result, it is reasonable for the spreadsheet calculation to results in less than that of the AAFC GHG's calculation.

For production of fertilizer, the application rate is 90 $\mathrm{kg} / \mathrm{ha}$ for each category including nitrogen, phosphate and potash. The area applied for each category is less than 2000 ha, which is 1300,1000 and 1000 ha respectively. Similarly to the AAFC GHG Calculator's result (460.4 $\mathrm{Mg} \mathrm{CO}_{2}$ ), the spreadsheet calculation shows the subtotal emission to be 461.5 $\mathrm{Mg} \mathrm{CO}_{2}$.

\section{CONCLUSION}

The total farm emission in the AAFC GHG Calculator is $3,960.2 \mathrm{Mg} \mathrm{CO}_{2}$ eq while the total farm emission of the spreadsheet is $2,963.1 \mathrm{Mg} \mathrm{CO}_{2}$ eq (Table 3). The spreadsheet total farm emission is less than the AAFC GHG Calculator because machine manufacture is not included in the spreadsheet. For the same categories, the AAFC GHG Calculator and spreadsheet agree within approximately $90 \%$.

This calculation and the Ontario case study shown below both demonstrate that the use of fertilizer contributes the most GHG emission thus the judicious use of nitrogen fertilizer is recomnmeded.

\section{ACKNOWLEDGEMENTS}

This project was funded by the Ontario Wheat Producer's Marketing Board (OWPB) with the help of the Stakeholder Manager, Erin Fletcher and the Research Manager, Crosby Devitt. In addition, Stephen Graham from SGA Energy Limited also helpfully provided the report Emission Factors and Uncertainties for $\mathrm{CH}_{4}$ and $\mathrm{H}_{2} \mathrm{O}$ from Fuel Combustion (2000). Moreover, Dr. Goretty Dias contributed a report titled "Stepwise Procedures for Estimation of Energy for Agricultural Inputs (Fertilizers, Pesticides, Seeds and Other By-Products) and Fuel Consumption of On- and Off-Road Transportation". Last by not least, Professor Claudia Wagner-Riddle, who is currently a professor at the School of Environmental Sciences in the 
Table 3 GHG emission results from spreadsheet.

\begin{tabular}{|c|c|c|c|c|}
\hline \multicolumn{2}{|c|}{ Pesticides } & Emission (kg CO2) & & \\
\hline Fungicides & & 66430 & & \\
\hline Insecticides & & 66534.4 & & \\
\hline Herbicides & & 66543.8 & & \\
\hline & Subtotal (Mg CO2) & 199.51 & & \\
\hline \multicolumn{2}{|c|}{ Operations } & Emission (kg CO2) & & \\
\hline \multicolumn{2}{|c|}{ Primary Tillage } & 204730.944 & & \\
\hline \multicolumn{2}{|c|}{ Secondary Tillage } & 60166.784 & & \\
\hline \multicolumn{2}{|c|}{ Chemical Application } & 21421.248 & & \\
\hline \multicolumn{2}{|l|}{ Cultivation } & 11471.488 & & \\
\hline \multicolumn{2}{|l|}{ Planting } & 73745.28 & & \\
\hline \multicolumn{2}{|l|}{ Harvesting } & 200702.184 & & \\
\hline & Subtotal (Mg CO2) & 572.24 & & \\
\hline \multicolumn{2}{|c|}{ Fertilizer Production \& Direct Emission } & $\begin{array}{l}\text { Fertilizer Production (kg } \\
\text { CO2) }\end{array}$ & $\begin{array}{c}\text { Direct } \\
\text { Emission } \\
(\mathrm{kg} \mathrm{CO2})\end{array}$ & $\begin{array}{l}\text { Indirect emission } \\
\quad(\mathrm{kg} \mathrm{CO})\end{array}$ \\
\hline Nitrogen & & 367380 & & \\
\hline Phosphate & & 54450 & 1367897.143 & 361671.75 \\
\hline \multirow[t]{3}{*}{ Potash } & & 39690 & & \\
\hline & Subtotal (kg CO2) & 461520 & 1367897.143 & 361671.75 \\
\hline & Total (Mg CO2) & & 2191.09 & \\
\hline \multicolumn{2}{|c|}{ Transportation } & Emission (kg CO2) & & \\
\hline \multicolumn{2}{|l|}{ Gasoline Truck } & 4.248 & & \\
\hline \multicolumn{2}{|l|}{$\begin{array}{l}\text { Gasoline } \\
\text { Vehicles }\end{array}$} & 1.9824 & & \\
\hline \multicolumn{2}{|l|}{ Diesel Truck } & 5.687955 & & \\
\hline \multicolumn{2}{|l|}{ Diesel Vehicles } & 17.063865 & & \\
\hline \multirow[t]{2}{*}{ Diesel Rail } & & 0 & & \\
\hline & Subtotal (Mg CO2) & 0.2898222 & & \\
\hline \multicolumn{2}{|c|}{ Total Emission (Mg CO2) } & 2963.12 & & \\
\hline
\end{tabular}

University of Guelph has guided me throughout the entire project.

\section{REFERENCES}

1. West, T.O., and G Marland. 2002. "A synthesis of carbon sequestration, carbon emissions, and net carbon flux in agriculture: comparing tillage practices in the
United States." AGRICULTURE ECOSYSTEMS \& ENVIRONMENT 91(1-3): 217-232.

2. Nagy, C. 2000. "Energy and Greenhouse Gas Emission Coefficients for Inputs used in Agriculture Report to the Prairie Adaptation Research Collaborative." Energy (December).

3. Rochette, P et al. 2008. "Estimation of N2O emissions from agricultural soils in Canada. I. Development of a 
country specific methodology.." Canadian Journal of Soil Science 88(5): pp. 641-654.."

4. Bowers, W. 1992." Agricultural field equipment." In In: Fluck, R.C. (Ed.), Energy in World Agriculture: Energy in Farm Production., Elsevier, Amsterdam., p. 117-129.

5. Dyer, J. A., and R L Desjardins. 2005. "A Simple MetaModel for Assessing the Contribution of Liquid Fossil Fuel for On-Farm Fieldwork to Agricultural Greenhouse Gases in Canada." Agriculture 27(1): 71-90.

6. Cervinka, V. 1980. "Fuel and energy efficiency. In: D. Pimentel (Editor), Handbook of Energy Utilization in Agriculture.." In: D. Pimentel (Editor), Handbook of Energy Utilization in Agriculture.: 15-21.

7. Lal, R. 2004. "Carbon emission from farm operations.." Environment international 30(7): 981-90. Available at: http://www.ncbi.nlm.nih.gov/pubmed/15196846.
8. Olsen, Ken et al. 2003. Canada 's Greenhouse Gas Inventory. Environment Canada. Ottawa, Ontario.

9. Helgason, B.L. et al. 2005. "GHGFarm An assessment tool for estimating net greenhouse gas emissions from Canadian farms." Agriculture.

10. Bushi, L. 2006. "Stepwise procedures for estimation of energy for agricultural inputs (fertilizers, pesticides, seeds and other by-products) and fuel consumption of on- and off-road transportation."

11. SGA. 2000. "Emission Factors and Uncertainties for CH4 \& N2O from Fuel Combustion." Combustion.

12. Börjesson, P.I.I. 1996. "Energy Analysis of Biomass Production and Transportation." Biomass and Bioenergy 11(4): 305-318. 